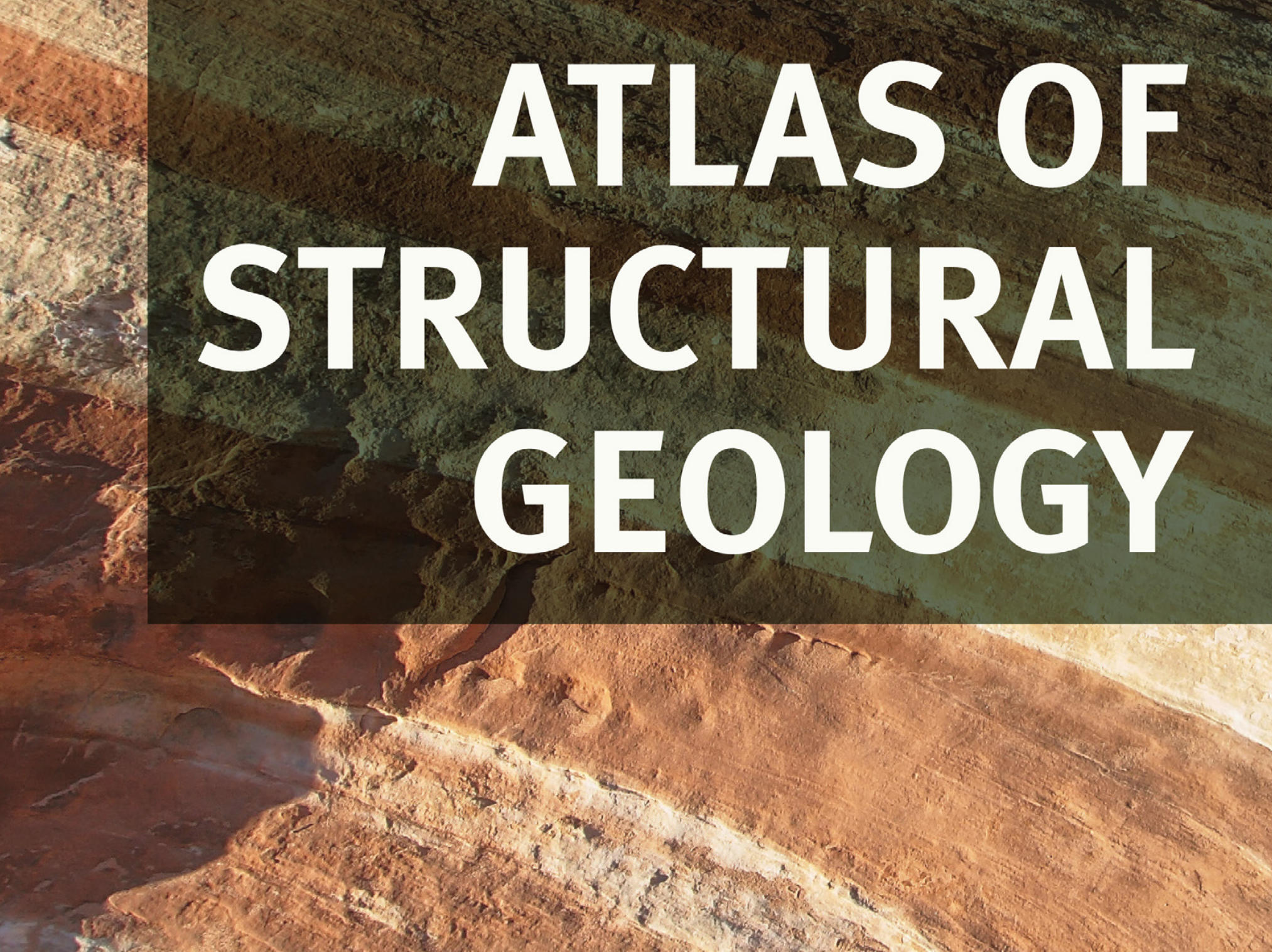
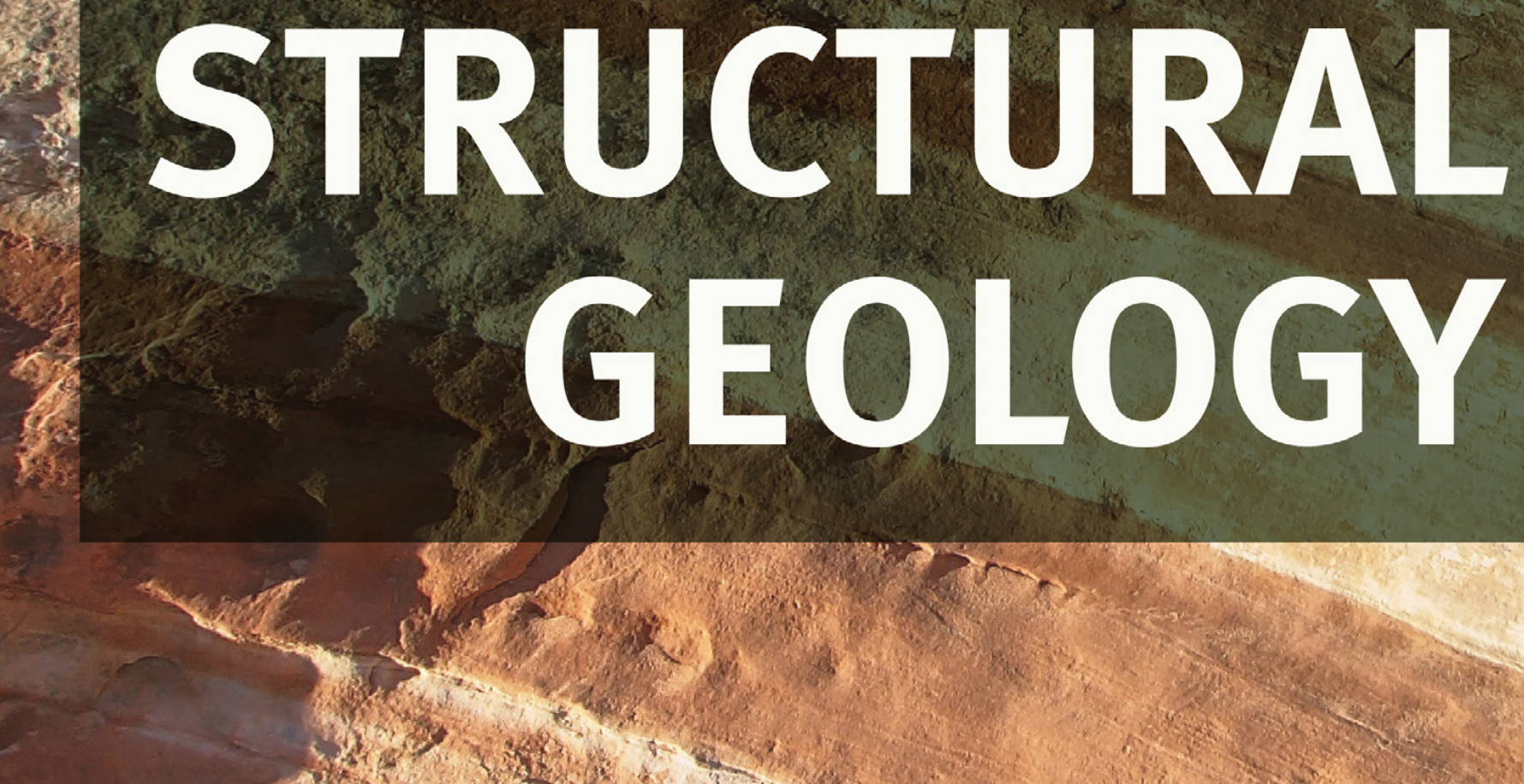

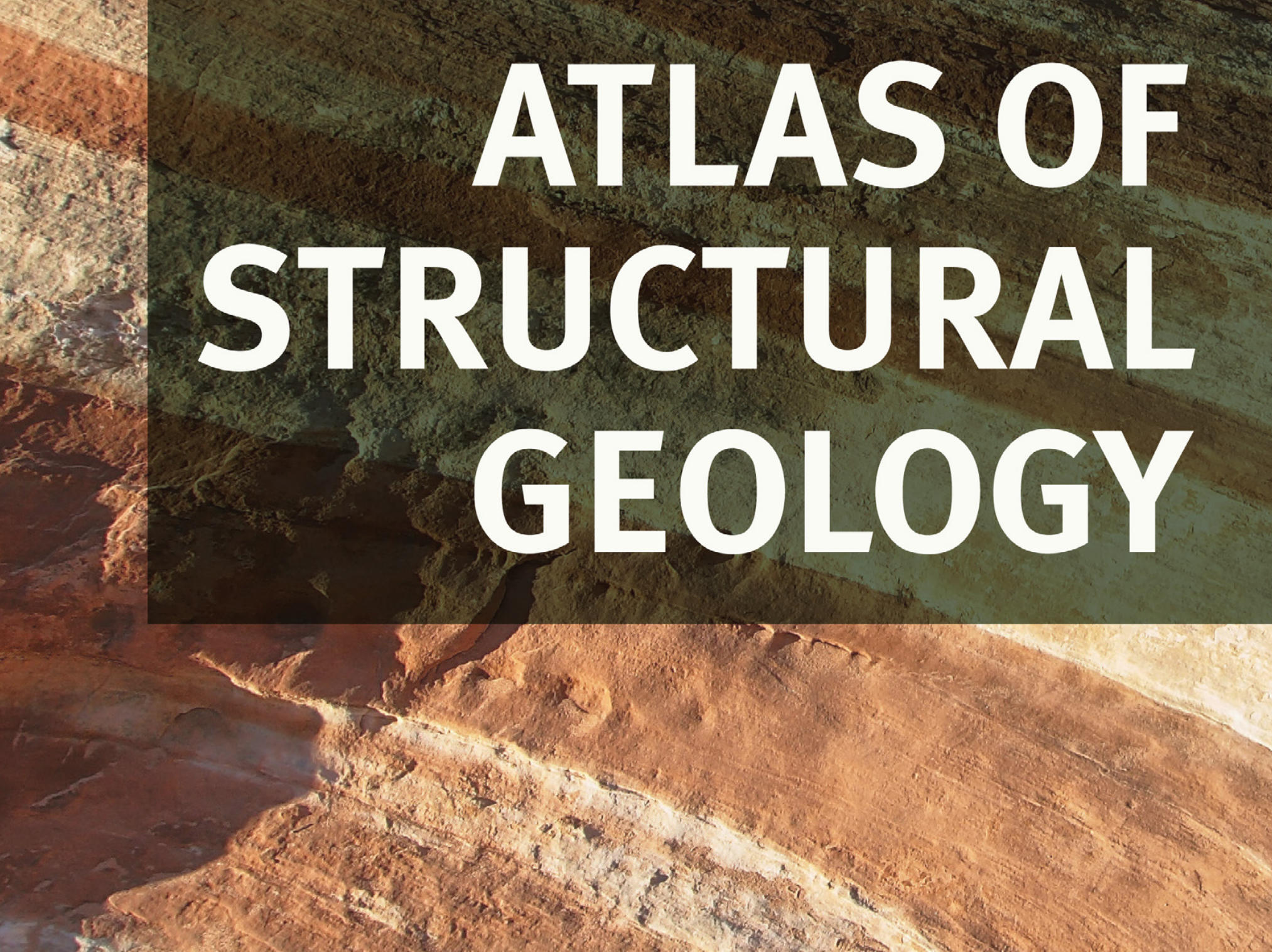

3.

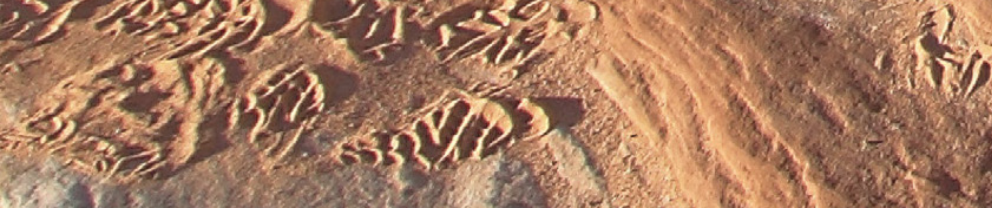




\section{Atlas of Structural Geology}

\section{Soumyajit Mukherjee}

Department of Earth Sciences

Indian Institute of Technology Bombay

Powai, Mumbai 400076

Maharashtra, India

soumyajitm@gmail.com

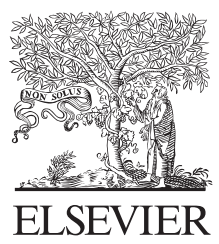


Elsevier

Radarweg 29, PO Box 211, 1000 AE Amsterdam, Netherlands

The Boulevard, Langford Lane, Kidlington, Oxford OX5 1GB, UK

225 Wyman Street, Waltham, MA 02451, USA

Copyright (C) 2015 Elsevier Inc. All rights reserved.

No part of this publication may be reproduced or transmitted in any form or by any means, electronic or mechanical, including photocopying, recording, or any information storage and retrieval system, without permission in writing from the publisher. Details on how to seek permission, further information about the Publisher's permissions policies and our arrangements with organizations such as the Copyright Clearance Center and the Copyright Licensing Agency, can be found at our website: www.elsevier.com/permissions.

This book and the individual contributions contained in it are protected under copyright by the Publisher (other than as may be noted herein).

\section{Notices}

Knowledge and best practice in this field are constantly changing. As new research and experience broaden our understanding, changes in research methods, professional practices, or medical treatment may become necessary.

Practitioners and researchers must always rely on their own experience and knowledge in evaluating and using any information, methods, compounds, or experiments described herein. In using such information or methods they should be mindful of their own safety and the safety of others, including parties for whom they have a professional responsibility.

To the fullest extent of the law, neither the Publisher nor the authors, contributors, or editors, assume any liability for any injury and/or damage to persons or property as a matter of products liability, negligence or otherwise, or from any use or operation of any methods, products, instructions, or ideas contained in the material herein.

ISBN: 978-0-12-420152-1

British Library Cataloguing in Publication Data

A catalogue record for this book is available from the British Library

Library of Congress Cataloging-in-Publication Data

A catalog record for this book is available from the Library of Congress

For Information on all Elsevier publications

visit our website at http://store.elsevier.com/

Printed and bound in the USA

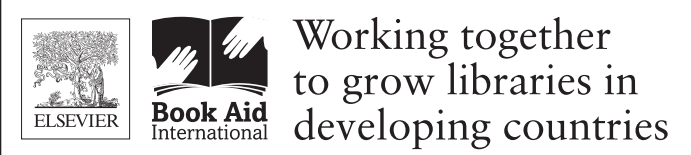

www.elsevier.com • www.bookaid.org 


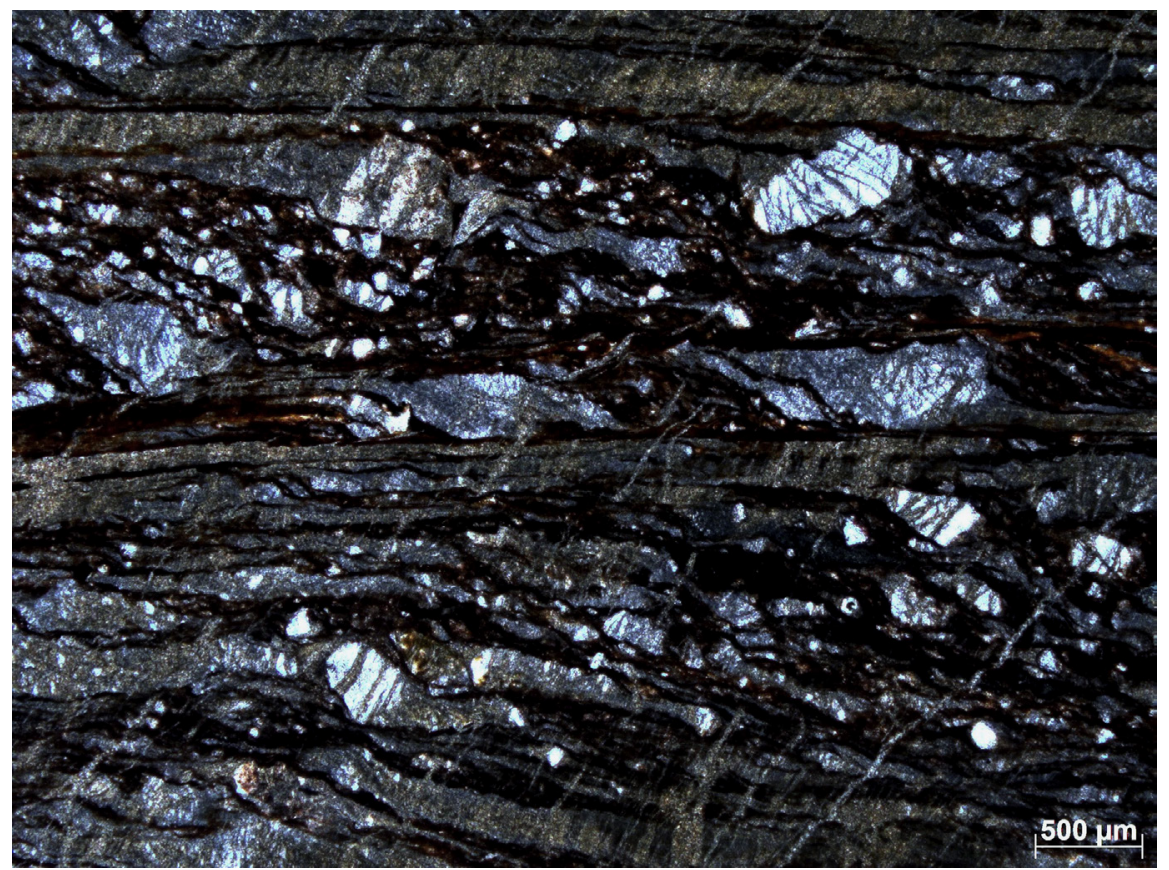

FIGURE 2.34 Sigma clasts, S-C structures in soft-sediment. Microstructures in $\sim 1-m$ thick clastic infill of a steeply dipping synsedimentary fault displaced Mesozoic rocks. Compositional bands in clastic infill parallel the fault. The major structures: calcite shear veins correspond to stacked slickenside fibers which occur along minor faults within the infill and parallel to main fault. Calcite fibers alter with millimeter-thick bands of clastic sediment (quartz and chert grains, clays with iron impregnation). Sigma clasts with calcitic tails indicate top-to-left shear. The quartz grains within the sigma clasts are intensely fractured and extended by calcite veinlets, which are also consistent with sinistral shear. In the lower part, parallel iron-impregnated dark clays bands correspond to S-foliation planes and merge with C-shear surfaces parallel to calcitic shear veins. Thus ductile S-C structure (Platt and Vissers, 1980) is defined. All these features are geometrically similar to structures found in crystal-plastically deformed metamorphic rocks. However, the sediment infill and host rocks are unmetamorphosed and were never buried below $2 \mathrm{~km}$. The interpretation is that the structures formed in unconsolidated state of the clastic infill, during the burial path of the sediment. The whole deformed zone is crosscut by the youngest parallel set of calcite veinlets, which could form after the complete diagenesis of the shear zone rocks. Middle Eocene sandstone, siltstone. Location: Vöröshíd quarry, Tardos village, Gerecse Hills, Hungary. Coordinates: $47^{\circ} 41^{\prime} 48.47^{\prime \prime} \mathrm{N}, 18^{\circ} 26^{\prime} 56.25^{\prime \prime} \mathrm{E}$. (László Fodor)

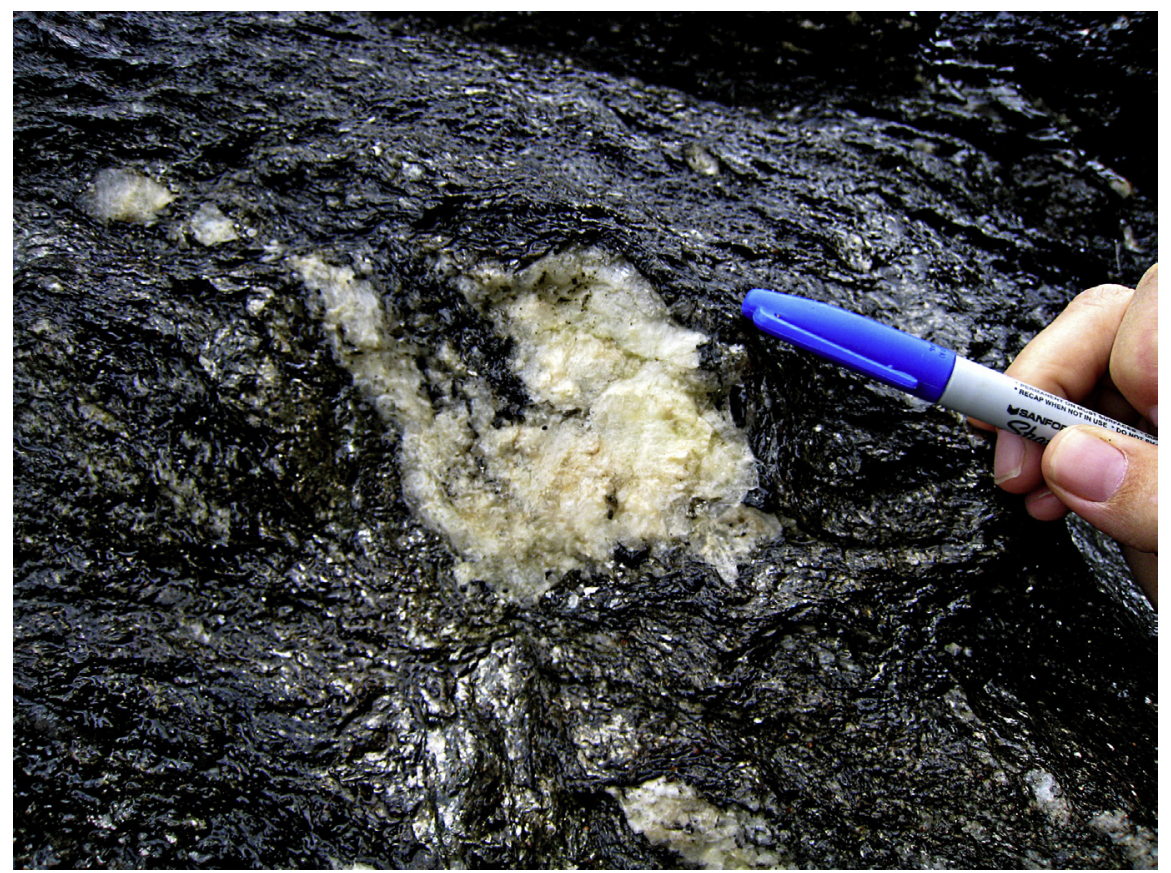

FIGURE 2.35 A top-to-left ductile sheared sigmoid quartz lens in kyanite-garnet gneiss, hanging wall rock of the Main Central thrust. Location: Unit I, Greater Himalaya, Kali-Gandaki section, Central Nepal Himalaya. (Subodha Khanal) 


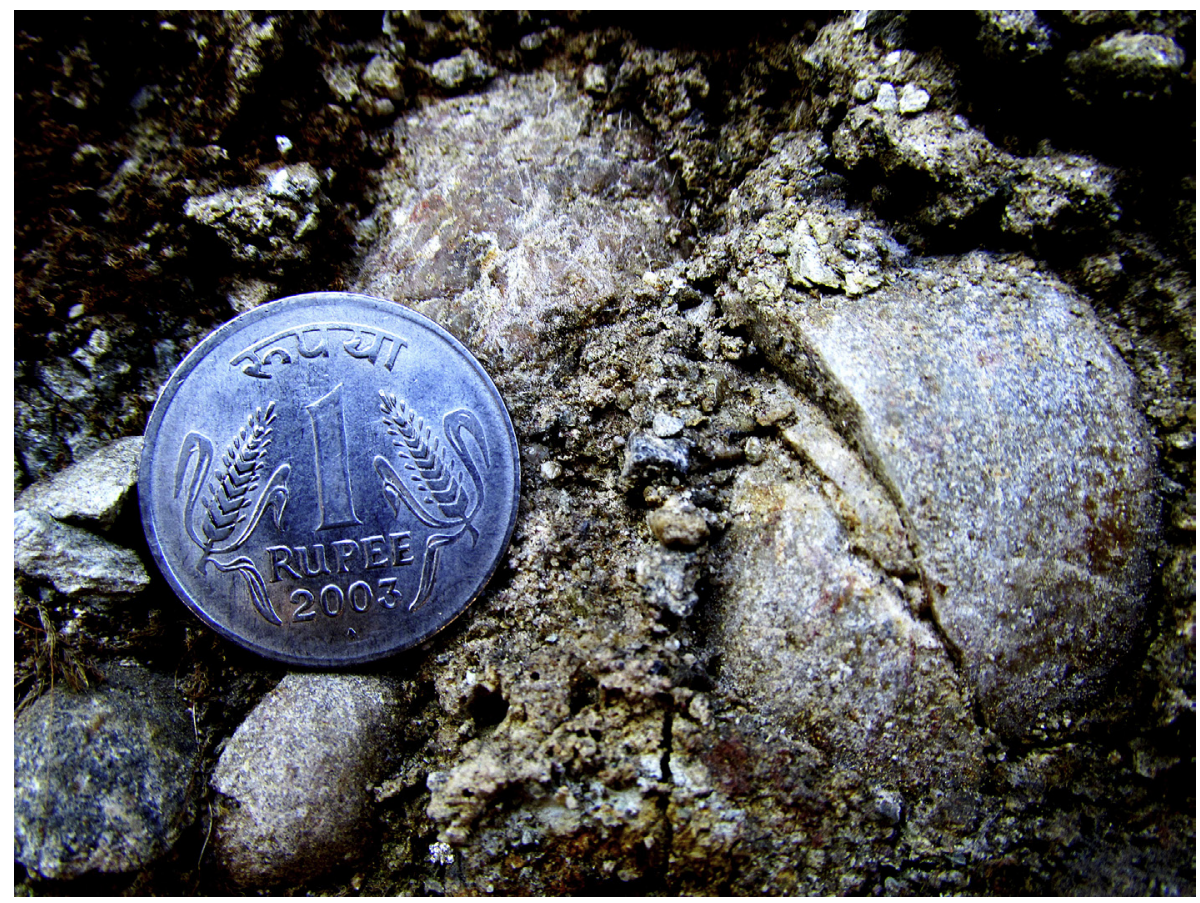

FIGURE 3.20 A N-dipping subvertical fault plane cut across quartzite pebble. Siwalik Supergroup conglomerate. Such a faulting indicates possibly an isostatic adjustment. Top-to-S (up) brittle shear. Near Mohand, Roorkee-Dehradun transect. $30^{\circ} 14.038^{\prime} \mathrm{N}, 77^{\circ} 56.9^{\prime}$ E. Uttarakhand, India. (Dripta Dutta)

FIGURE 3.21 Along-dip segmented normal fault and fault-related fold in Jurassic sequence. Three fault segments dissect the condensed pelagic Jurassic sequence: one single planar plane in the lower part, two in the Tölgyhát Formation, one above the lower segment and one to the left (Sasvári et al., 2009). This disposition is typical for along-dip segmented norma faults (Childs et al., 1996; Rykkelid and Fossen, 2002). Between segments the deformation accommodated in the thin marlstone unit. The upper marlstone layers show folding between fault segments. The lower gray clay layers are boudinaged/pinched along the lower fault segment. Note the hanging wall part is present in the shadow of the marlstone layers. This different behavior could occur because of contrasting rheology of the deforming rocks. The segmented fault can have Middle Jurassic age (Bathonian, 168-166 Ma) because at least one upper segment is covered by Middle to Late Jurassic (Callovian-Oxfordian) radiolarite beds (Fodor et al., 2013). This early formation time matches with folding of the Toarcian unit, which deformed before complete diagenetic cementation, still in a semiplastic stage. The E-W-trending fault accommodated minor extension of a downbending side of a foreland basin opposite to the growing Dinaridic orogen (Fodor et al., 2013). Blue rucksack: $\sim 50 \mathrm{~cm}$. Early Jurassic limestone, late Early Jurassic (Toarcian) marlstone-claystone, Middle Jurassic nodular limestone of Tölgyhát Formation. Location: Tölgyhát quarry, Lábatlan village, Gerecse Hills, Hungary. Coordinates: $47^{\circ} 43^{\prime 2} 20.92^{\prime \prime} \mathrm{N}, 18^{\circ} 30^{\prime}$ 45.80"E. (László Fodor)

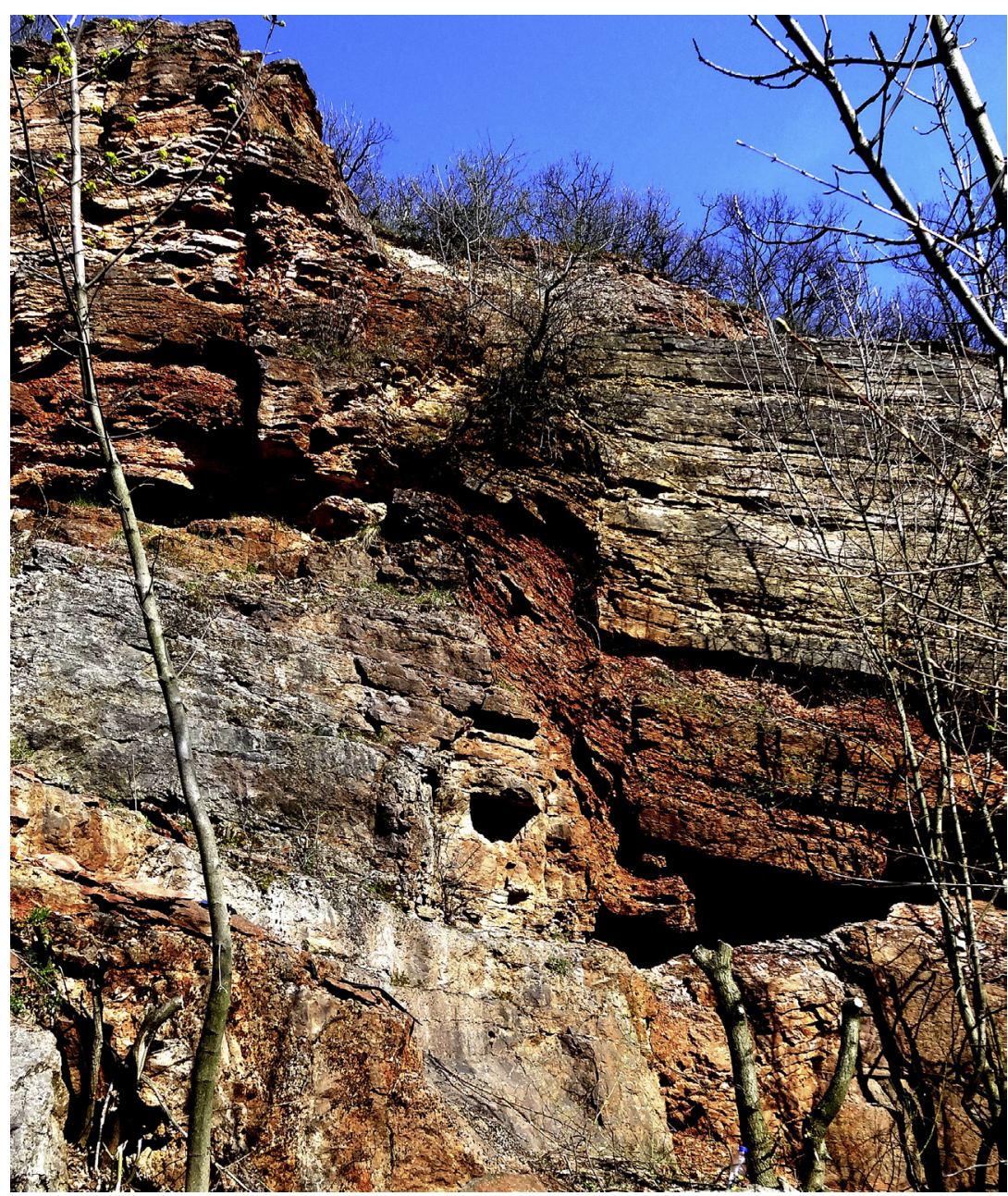




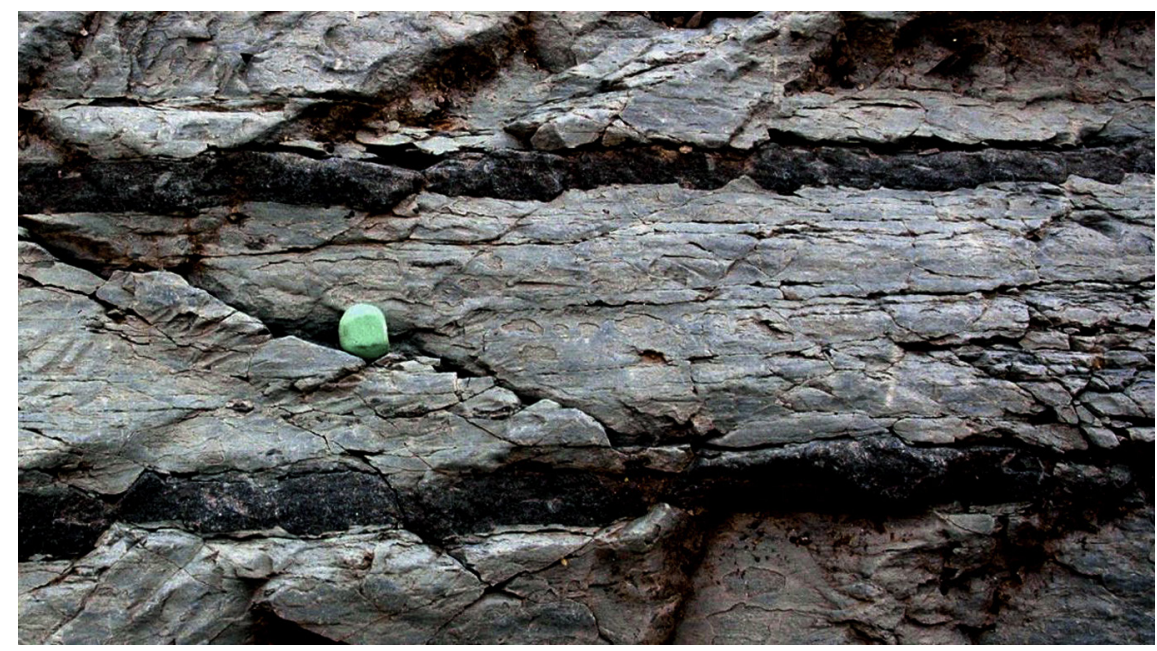

FIGURE 3.44 Synlithification faults in Cretaceous clastics. In the gray marl, the centimeter-thick sandstone layers commonly contain a set of small, parallel displacement zones, which cannot be followed up to the next sandstone bed. Within the sandstone, the fault planes are frequently not discrete surfaces and are macroscopically invisible. They either do not continue in the intercalating marlstone or occur as closed fractures. In addition, displacement lines at the upper and lower boundaries of the sandstone bed are not always aligned but are en-echelon along dip direction. This can be interpreted as along-dip segmented fractures. Displacement can be smaller at the upper than at the lower bedding plane. All these deformation features developed when sandstone beds consolidated/cemented partly and were in plastic state so they are synlithification faults. The deformation can be regarded as a first step for boudinage. Deformation occurred during the Early Cretaceous progressive burial. Compaction affected the conjugate fracture set and increased their angle to obtuse angle. Postdeformation cementation sealed the early displacement features. The deformation is related to an Early Cretaceous foreland basin formation (Tari, 1994; Fodor et al., 2013). Green eraser: 2 cm. Early Cretaceous (Valanginian) marlstone, sandstone (Fogarasi, 1995). Location: Bersek quarry, Lábatlan village, Gerecse Hills, Hungary. Coordinates: 4743’20.33”N, 18³1'29.13”E. (László Fodor)

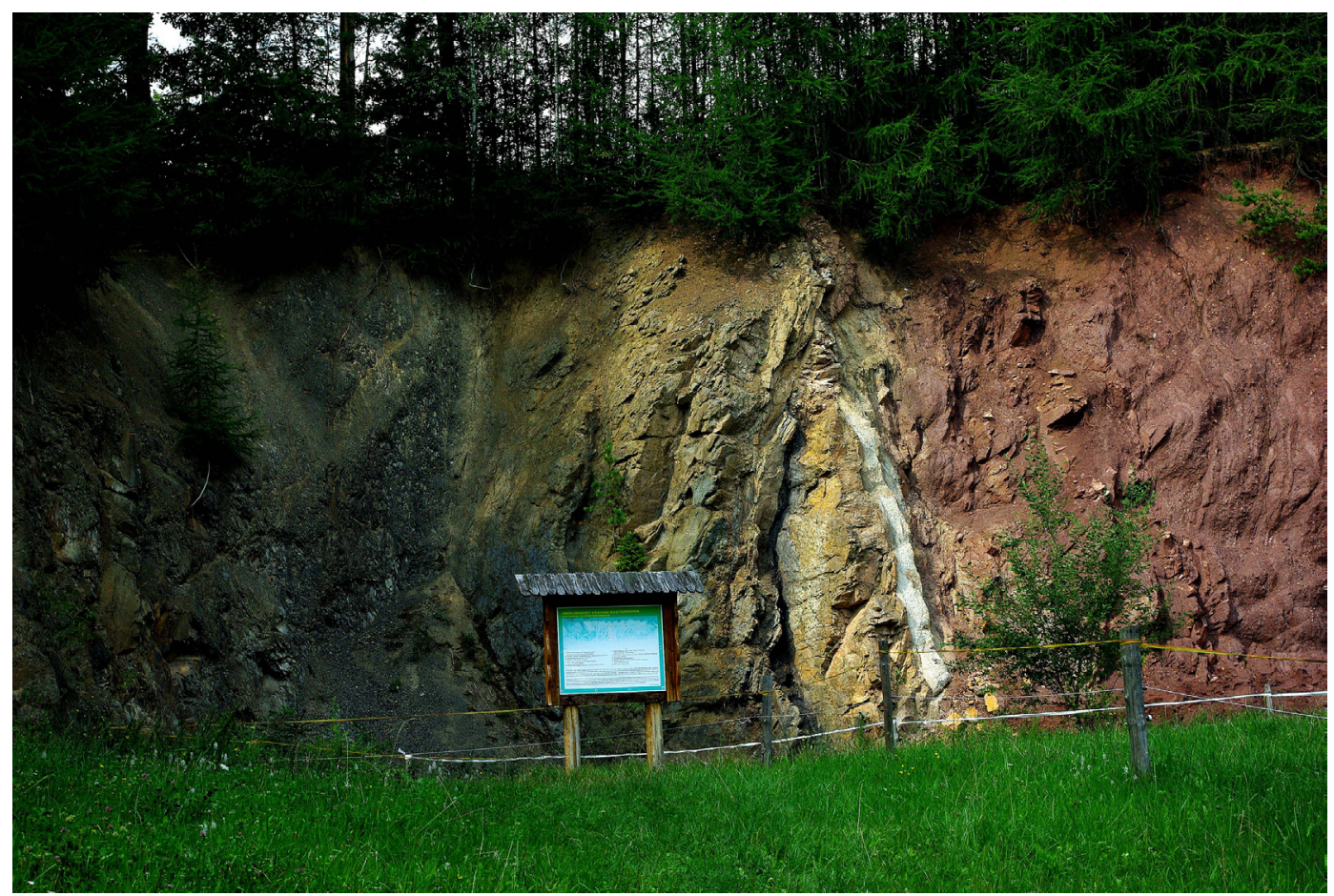

FIGURE 3.45 The outcrop exposes one of the main faults of the active Hronov-Poříčí Fault Zone, Czech Republic. It is $\sim 70-\mathrm{km}$ long intraplate zone responsible for earthquakes up to M 4.7 recently (Woldrich, 1901; Špaček et al., 2006). Red-brown Permian conglomerates and breccias of the Trutnov Formation on the right side form hanging wall of the fault zone. Conglomerates are overlain unconformably by ochre to dark gray Cretaceous sandstones and siltstones of the Peruc-Korycany Formation, cropping out on left side of the wall (see Novakova, 2014). The dip of both the Permian and the Cretaceous sediments is steep (up to $89^{\circ} \mathrm{SW}$ ) due to the close vicinity of the main fault line. The Hronov-Poŕíći Fault Zone represents main reverse fault accompanied by parallel/oblique normal or reverse faults (Valenta et al., 2011). GPS coordinates: N50³2'14", E01602'31'. (Lucie Novakova) 


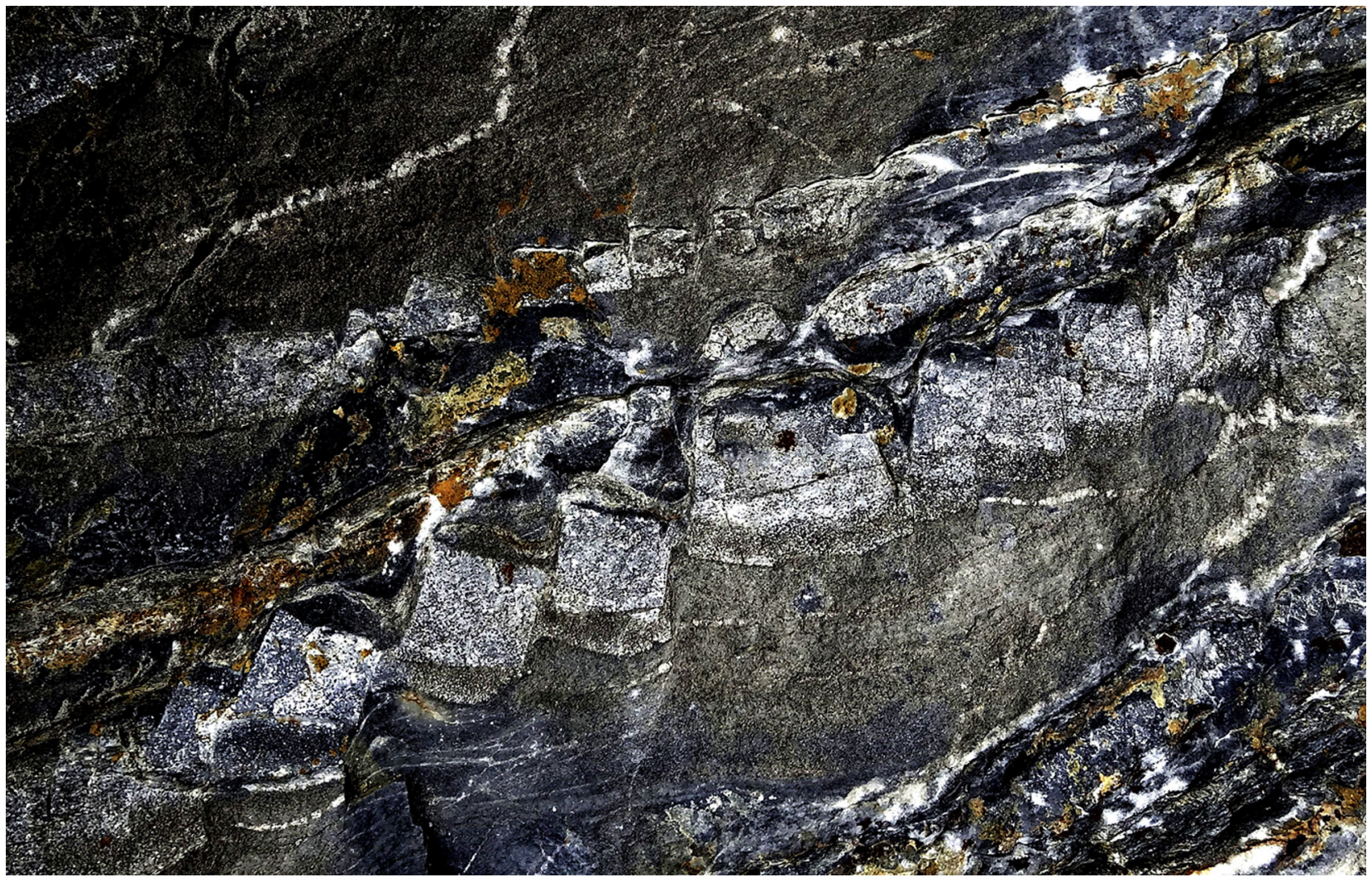

FIGURE 4.12 Asymmetric rotating domino boudins within low-grade metamorphic carbonate sequence. The domino boudins are made up of dolomite, while the surrounding rock is calcite marble. At low-grade conditions, dolomite intercalations act as more competent layers. The calcite marble deforms crystal plastically forming foliated calcite mylonite. The intercalated dolomite layers remain nearly rigid and disrupt into rectangular boudins. Rectangular shape of the dolomite dominos indicates high viscosity contrast during deformation (Fossen, 2010). The domino boudins are asymmetric ones and parallel mylonitic foliation. The individual dominos are separated by small-scale shear zones that die out as soon as they leave the dolomite layer. Some dilatation occur across the inter-boudin surfaces. Significant rotation of the domino boudins are present, which kept the row of boudins aligned with the general foliation of the calcite mylonite. The stretch magnitude varies along the boudin layers, but usually remains low. Rarely domino boudins separate completely. Asymmetric domino boudins indicate sinistral shear. Other shear criteria in field confirmed this. However, asymmetric boudins can be problematic shear-sense indicators (Goscombe and Passchier, 2003), thus require additional studies. Triassic limestone and dolomite (Schefer et al., 2010). Photo width $\sim 20 \mathrm{~cm}$. Brzeće, Kopaonik Mts., SE Serbia. Coordinates: N43 ${ }^{\circ} 8^{\prime}$ 44.05", E2050'59.75". (László Fodor) 


\section{Contents}

List of Contributors vii

Preface xiii

Acknowledgments $\mathrm{xv}$

1. Folds 1

2. Ductile Shear Zones 49

3. Brittle Faults 79

4. Boudins and Mullions 107

5. Veins 119

6. Various Structures 125

Author Index 159

Subject Index 163 


\section{Preface}

Documentation of structures in different scales is the first step in many structural geological studies. This edited atlas gives an overview of diverse structures. Due to lack of space or inappropriateness, sometimes interesting structural snaps cannot be published in journals. This book fills that gap. 


\section{Acknowledgments}

Thanks to Mohanapriyan Rajendran, Priya Srikumar, Marisa LaFleur, Amy Shapiro, Louisa Hutchins, and John Fedor (Elsevier) for editing, and to all the contributors and reviewers. Philippe Herve Leloup, Chris Talbot and an anonymous reviewer are thanked for reviewing the book proposal and for providing positive comments. Research students and teaching assistants helped and I thank them: Tuhin Biswas, Narayan Bose, Achyuta Ayan Misra, Aninda Ghosh, Rajkumar Ghosh, Dripta Dutta, Uddipan Das, and many others. Thanks to my wife Payel Mukherjee for her patience. 
Denyer, P., Alvarado, G.E., 2007. Mapa geológico de Costa Rica. Escala 1:400.000. Librería Francesa, San José, Costa Rica.

Derez, T., Pennock, G., Drury, M., Sintubin, M., 2015. Low-temperature intracrystalline deformation microstructures in quartz. Journal of Structural Geology 71, 3-23.

Dillon, J.T., Brosge, W.P., Dutro, J.T., 1986. Generalized Geologic Map of the Wiseman Quadrangle. US Geological Survey Open-File Report 86-219, Alaska.

Eriksson, P.G., Porada, H., Banerjee, S., Bouougri, E., Sarkar, S., Bumby, A.J., 2007. In: Schieber, J., Bose, P.K., Eriksson, P.G., Banerjee, S., Sarkar, S., Altermann, W., Catuneau, O. (Eds.), Atlas of Microbial Mat Features Preserved within the Siliciclastic Rock Record. Elsevier, pp. 76-105.

Faccenna, C., Soligo, M., Billi, A., De Filippis, L., Funiciello, R., Rossetti, C., Tuccimei, P., 2008. Late Pleistocene depositional cycles of the Lapis Tiburtinus travertine (Tivoli, central Italy): possible influence of climate and fault activity. Global and Planetary Change 63, $299-308$.

Fagereng, A., 2011. Frequency-size distribution of competent lenses in a block-in-matrix melange: imposed length scales of brittle deformation? Journal of Geophysical Research 116, B05302.

French, B.M., Koeberl, C., 2010. The convincing identification of terrestrial meteorite impact structures: what works, what doesn't, and why. EarthScience Reviews 98, 123-170.

Frid, V., Bahat, D., Rabinovich, A., 2005. Analysis of en echelon/hackle fringes and longitudinal splits in twist failed glass samples by means of fractography and electromagnetic radiation. Journal of Structural Geology 27, 145-159.

Fujimoto, Y., Yamamoto, M., 2010. On the granitoids in the Shirakami mountains and correlation to the Cretaceous to Paleogene granitoids distrtibuted in the Northeast Japan. Earth Science 64, 127-144. In Japanese with English abstract.

Gay, N.C., 1974. Modification of deformation lamellae during brittle-ductile deformation of quartzite. Geological Society of America Bulletin 85, $1237-1242$

Gehrels, G.E., DeCelles, P.G., Ojha, T.P., Upreti, B.N., 2006. Geologic and U-Th-Pb geochronologic evidence for early Paleozoic tectonism in the Kathmandu thrust sheet, central Nepal Himalaya. Geological Society of America Bulletin 118, 185-198.

Gratier, J.-P., Frery, E., Deschamps, P., Røyne, A., Renard, F., Dysthe, D., Ellouz- Zimmerman, N., Hamelin, B., 2012. How travertine veins grow from top to bottom and lift the rocks above them: the effect of crystallization force. Geology 40, 1015-1018.

Grützner, C., Reicherter, K., Hübscher, C., Silva, P.G., 2012. Active faulting and neotectonics in the Baelo Claudia area, Campo de Gibraltar (southern Spain). Tectonophysics 554-557, 127-142.

Hamers, M.F., Drury, M.R., 2011. Scanning electron microscope-cathodoluminescence (SEM-CL) imaging of planar deformation features and tectonic deformation lamellae in quartz. Meteorites \& Planetary Science 46, 1814-1831.

Hancock, P.L., Chalmers, R.M.L., Altunel, E., Çakir, Z., 1999. Travitonics: using travertine in active fault studies. Journal of Structural Geology 21, 903-916.

Hefferan, K., O’Brien, J., 2010. Earth Materials. John Wiley \& Sons Ltd, Wiley-Blackwell, UK.

Hobbs, B.E., Means, W.D., Williams, P.F., 1976. An Outline of Structural Geology. John Wiley \& Sons.

Hurst, A., Scott, A., Vigorito, M., 2011. Physical characteristics of sand injectites. Earth-Science. Reviews 106, 215-246.

Knauth, L.P., 1979. A model for the origin of chert in limestone. Geology 7, 274-277.

Kamai, R., Hatzor, Y.H., 2008. Numerical analysis of block stone displacements in ancient masonry structures: a new method to estimate historic ground motions. International Journal for Numerical and Analytical Methods in Geomechanics 32, 1321-1340.

Kamh, G.M.E., Kallash, A., Azzam, R., 2008. Factors controlling building susceptibility to earthquakes: 14-year recordings of Islamic archaeological sites in old Cairo, Egypt: a case study. Environmental Geology 56, 269-279.

Karakhanian, A.S., Trifonov, V.G., Ivanova, T.P., Avagyan, A., Rukieh, M., Minini, H., Dodonov, A.E., Bachmanov, D.M., 2008. Seismic deformation in the St. Simeon monasteries (Qal'at Sim'an), northwestern Syria. Tectonophysics 453, 122-147.

Kázmér, M., Damages to ancient buildings from earthquakes. In: Beer M., Patelli E., Kouigioumtzoglou I., Au, I.S-K. (Eds.), Encyclopedia of Earthquake Engineering, Springer, Berlin, submitted for publication.

Kázmér, M., Major, B., 2010. Distinguishing damages of two earthquakes - archeoseismology of a Crusader castle (Al-Marqab citadel, Syria). In: Sintubin, M., Stewart, I., Niemi, T., Altunel, E. (Eds.), Ancient Earthquakes, vol. 471. Geological Society of America Special Paper, pp. $186-199$.

Korjenkov, A.M., Mazor, E., 2003. Archeoseismology in Mamshit (Southern Israel): cracking a millennium-old code of earthquakes preserved in ancient ruins. Archäologischer Anzeiger 2003 (2), 51-82.

Korjenkov, A.M., Mazor, E., 1999. Seismogenic origin of the ancient Avdat ruins, Negev desert. Israel Natural Hazards 18, $193-226$.

Krishnan, S., Ji, C., Komatitsch, D., Tromp, J., 2006. Case studies of damage to tall steel moment-frame buildings in southern California during large San Andreas earthquakes. Bulletin of the Seismological Society of America 96, 1523-1537.

Kukla, P.A., Stanistreet, I.G., 1991. Record of the Damaran Khomas Hochland accretionary prism in central Namibia: Refutation of an "Ensialic" origin of a Late Proterozoic orogenic belt. Geology 19, 473-476.

Ludman, A., West, Jr., D.P., (Eds.). 1999. The Norumbega fault system of the northern Appalachians. Geological Society of America Special Paper 331,199

Marco, S., 2008. Recognition of earthquake-related damage in archaeological sites: examples from the Dead Sea fault zone. Tectonophysics 453, $148-156$.

Meghraoui, M., Gomez, F., Sbeinati, R., Van der Woerd, J., Mouty, M., Darkal, A.N., Radwan, Y., Layyous, I., Al Najjar, H., Darawcheh, R., Hijazi, F., Al-Ghazzi, R., Barazangi, M., 2003. Evidence for 830 years of seismic quiescence from paleoseismology, archaeoseismology and historical seismicity along the Dead Sea Fault in Syria. Earth and Planetary Science Letters 210, 35-52.

Meneghini, F., Kisters, A., Buick, I., Fagereng, A., 2014. Fingerprints of Late Neoproterozoic Ridge Subduction in the Pan-African. Geology, Damara belt, Namibia. Geology 42, 903-906. 
Millán, H., Pocoví, A., Casas, A., 1995. El frente de cabalgamiento surpirenaico en el extremo occidental de las Sierras Exteriores: sistemas imbricados y pliegues de despegue. Revista de la Sociedad Geológica de España 8, 73-90.

Mooney, W., Beroza, G., Kind, R., 2007. Fault zones from top to bottom. In: Handy, M.R., Hirth, G., Hovius, N. (Eds.), Tectonic Faults - Agents of Change on a Dynamic Earth. The MIT Press, Cambridge, Mass., USA, pp. 2-46. Dahlem Workshop Report 95.

Mukherjee, S., 2010. V-pull apart structure in garnet in macro-scale. Journal of Structural Geology 32, 605.

Mukherjee, S., 2012. Simple shear is not so simple! Kinematics and shear senses in Newtonian viscous simple shear zones. Geological Magazine 149, $819-826$.

Mukherjee, S., 2013. Deformation Microstructures in Rocks. Springer.

Mukherjee, S., 2014. Atlas of Shear Zone Structures in Meso-scale. Springer.

Muñoz, J.A., Beamud, E., Fernández, O., Arbués, P., Dinarès-Turell, J., Poblet, J., 2013. The Ainsa fold and thrust oblique zone of the central Pyrenees: kinematics of a curved contractional system from paleomagnetic and structural data. Tectonics 32, 1142-1175.

Nichols, G.J., 1987. The Structure and Stratigraphy of the Western External Sierras of the Pyrenees, Northern Spain. Geological Journal 22, 245-259.

Novakova, L., 2008. Main directions of the fractures in the limestone and granite quarries along the Sudetic Marginal Fault near Vápenná village, NE Bohemian Massif, Czech Republic. Acta Geodynamica et Geomaterialia 5, 49-55.

Novakova, L., Hájek, P., Štastný, M., 2010. Determining the relative age of fault activity through analyses of gouge mineralogy and geochemistry: a case study from Vápenná (Rychlebské hory Mts.), Czech Republic. International Journal of Geosciences 1, 66-69.

Oliva-Urcia, B., Casas, A.M., Pueyo, E.L., Pocoví, A., 2012a. Structural and paleomagnetic evidence for non-rotational kinematics in the western termination of the External Sierras (southwestern central Pyrenees). Geologica Acta 10, 1-22.

Osanai, Y., Nogi, Y., Baba, S., Nakano, N., Adachi, T., Hokada, T., Toyoshima, T., Owada, M., 2013. Geologic evolution of the Sør Rondane Mountains, East Antarctica: collision tectonics proposed based on metamorphic processes and magnetic anomalies. Precambrian Research $234,8-29$.

Owada, M., Osanai, Y., Tsunogae, T., Hamamoto, T., Kagami, H., Toyoshima, T., Hokada, T., 2001. Sm-Nd garnet ages of retrograde garnet bearing granulites from Tonagh Island in the Napier Complex, East Antarctica: a preliminary study. Polar Geoscience 14, 75-87.

Pease, V., Argent, J., 1999. The northern Sacramento mountains, SW United States, Part I: structural profile through a crustal extensional detachment system. In: MacNiocaill, C., Ryan, P. (Eds.), Continental Tectonics, vol. 164. Geological Society of London Special Publication, pp. $179-198$.

Pease, V., Foster, D., Wooden, J., O’Sullivan, P., Argent, J., Fanning, C., 1999. The northern Sacramento mountains, SW United States, Part II: exhumation history and detachment faulting. In: MacNiocaill, C., Ryan, P. (Eds.), Continental Tectonics, vol. 164. Geological Society of London Special Publication, pp. 199-237.

Pueyo, E.L., Parés, J.M., Millán, H., Pocoví, A., 2003a. Conical folds and apparent rotations in paleomagnetism (a case study in the Pyrenees). Tectonophysics 362, 345-366.

Passchier, C.W., Trouw, R.A.J., 2005. Microtectonics. Springer-Verlag, Berlin.

Pau, A., Vestroni, F., 2008. Vibration analysis and dynamic characterization of the Colosseum. Structural Control and Health Monitoring 15, 1105-1121.

Price, N.A., Johnson, S.E., Gerbi, C.C., West Jr., D.P., 2012. Identifying deformed pseudotachylyte and its influence on the strength and evolution of a crustal shear zone at the base of the seismogenic zone. Tectonophysics 518-521, 63-83.

Ree, J.H., Kwon, S.H., Park, Y., 2001. Pretectonic and posttectonic emplacements of the granitic rocks in the south central Okcheon belt, South Korea: Implications for the timing of strike-slip shearing and thrusting. Tectonics 20, 850-867.

Rhodes, M.K., Malone, D.H., Carroll, A.R., 2007. Sudden desiccation of Lake Gosiute at 49 Ma: Downstream record of Heart Mountain faulting? The Mountain Geologist 44, 1-10.

Rodríguez-Pascua, M.A., Pérez-López, R., Silva, P.G., Giner-Robles, J.L., Garduño-Monroy, V.H., Reicherter, K., 2011. A comprehensive classification of earthquake archaeological effects (EAE) for archaeoseismology. Quaternary International 242, 20-30.

Samanta, S.K., Mandal, N., Chakraborty, C., 2001. Development of different types of pull-apart microstructures in mylonites: an experimental investigation. Journal of Structural Geology 24, 1345-1355.

Séguret, M., 1972. Etude tectonique des nappes et séries décollées de la partie centrale du versant sud des Pyrénées (PhD. thesis). Caractère synsédimentaire, rôle de la compression et de la gravité. University of Montpellier.

Silva, P.G., Borja, F., Zazo, C., Groy, J.L., Bardají, T., De Luque, L., Lario, J., Dabrio, C.J., 2005. Archaeoseismic record at the ancient Roman city of Baelo Claudia (Cádiz, south Spain). Tectonophysics 408, 129-146.

Sibson, R.H., Toy, V.G., 2006. The habit of fault-generated pseudotachylyte: Presence vs. absence of friction-melt. In: Earthquakes: Radiated Energy and the Physics of Faulting. Geophysical Monograph Series 170, 153-166.

Similox-Tohon, D., Sintubin, M., Muchez, P., Verhaert, G., Vanneste, K., Fernandez, M., Vandycke, S., Vanhaverbeke, H., Waelkens, M., 2006. The identification of an active fault by a multidisciplinary study at the archaeological site of Sagalassos (SW Turkey). Tectonophysics 420, $371-397$. Erratum: 435, pp. 55-62.

Simpson, C., 1985. Deformation of granitic rocks across the brittle-ductile transition. Journal of Structural Geology 7, 503-511.

Stipp, M., Stunitz, H., Heilbronner, R., Schmid, S.M., 2002. The eastern Tonale fault zone: a 'natural laboratory' for crystal plastic deformation of quartz over a temperature range from 250 to 700 C. Journal of Structural Geology 24, 1861-1884.

Takahashi, Y., 1999. Reexamination on the northern extension of the Tanagura Tectonic Line, with special reference to the Nihonkoku-Miomote Mylonite Zone. Structural Geology 43, 69-78. In Japanese with English abstract.

Takahashi, Y., 2002. Granitic mylonites situated around the Shirakami Mountains. Northeast Japan. Earth Science 56, 215-216. In Japanese.

Takahashi, Y., Cho, D.L., Kee, W.S., 2010. Timing of mylonitization in the Funatsu Shear Zone within Hida Belt of southwest Japan: Implications for correlation with the shear zones around the Ogcheon Belt in the Korean Peninsula. Gondwana Research 17, 102-115. 
Tänavsuu-Milkeviciene, K., Sarg, F.J., 2012. Evolution of an organic-rich lake basin - stratigraphy, climate and tectonics: Piceance Creek basin, Eocene Green River Formation. Sedimentology 59, 1735-1768.

Ternet, Y., Baudin, T., Laumonier, B., Barnolas, A., Gil-Peña, I., Martín-Alfageme, S., 2008. Mapa Geológico de los Pirineos a E. 1: 400.000. IGMEBRGM, Madrid-Orleans.

Till, A.B., Dumoulin, J.A., Harris, A.G., Moore, T.E., Bleick, H.A., Siwiec, B.R., 2008. Bedrock Geologic Map of the Southern Brooks Range, Alaska, and Accompanying Conodont Data. US Geological Survey Open-File Report 2008-1149. 54 pp.

Törő, B., Pratt, B.R., Renaut, R.W., 2013. Seismically induced soft-sediment deformation structures in the Eocene lacustrine Green River Formation (Wyoming, Utah, Colorado, USA) - a preliminary study. Poster abstract, Calgary. GeoConvention 2013: Integration Calgary. Poster abstract.

Toyoshima, T., Osanai, Y., Baba, S., Hokada, T., Nakano, N., Adachi, T., Otsubo, M., Ishikawa, M., Nogi, Y., 2013. Sinistral transpressional and extensional tectonics in Dronning Maud Land, East Antarctica, including the Sør Rondane Mountains. Precambrian Research 234, 30-46.

Toyoshima, T., Osanai, Y., Owada, M., Tsunogae, T., Hokada, T., Crowe, W.A., 1999. Deformation of ultrahigh-temperature metamorphic rocks from Tonagh Island in the Napier Complex, East Antarctica. Polar Geoscience 12, $29-48$.

Toyoshima, T., Owada, M., Shiraishi, K., 1995. Structural evolution of metamorphic and intrusive rocks from the central part of the Sør Rondane Mountains, East Antarctica. Proceedings of the NIPR Symposium on Antarctic Geosciences 8, 75-97.

Treiman, A.H., 2008. Ancient groundwater flow in the Valles Marineris on Mars inferred from fault trace ridges. Nature Geoscience 1, $181-183$.

Trepmann, C.A., Stockhert, B., Dorner, D., Moghadam, R.H., Kuster, M., Roller, K., 2007. Simulating coseismic deformation of quartz in the middle crust and fabric evolution during postseismic stress relaxation - An experimental study. Tectonophysics 442, 83-104.

Tullis, T.E., Bürgmann, R., Cocco, M., Hirth, G., King, G.C.P., Oncken, O., Otsuki, K., Rice, J.R., Rubin, A., Segall, P., Shapiro, S.A., Wibberley, C.A.J., 2007. Group report: rheology of fault rocks and their surroundings. In: Handy, M.R., Hirth, G., Hovius, N. (Eds.), Tectonic Faults - Agents of Change on a Dynamic Earth. Dahlem Workshop Report 95. The MIT Press, Cambridge, Mass, USA, pp. 183-204.

Twiss, R.J., Moores, E.M., 2007. Structural Geology. WH Freeman and Company. New York. pp. 43-45.

Uysal, I.T., Feng, Y., Zhao, J.X., Isik, V., Nuriel, P., Golding, S.D., 2009. Hydrothermal $\mathrm{CO}_{2}$ degassing in seismically active zones during the Late Quaternary. Chemical Geology 265, 442-454.

Uysal, I.T., Feng, Y., Zhao, J.X., Altunel, E., Weatherley, D., Karabacak, V., Cengiz, O., Golding, S.D., Lawrence, M.G., Collerson, K.D., 2007. U-series dating and geochemical tracing of late Quaternary travertine in co-seismic fissures. Earth and Planetary Science Letters 257, 450-462.

Van Baelen, H., 2010. Dynamics of a progressive vein development during the late-orogenic mixed brittle-ductile destabilisation of a slate belt. Examples of the High-Ardenne slate belt (Herbeumont, Belgium). Aardkdundige Mededelingen 24, 221p.

Van Daalen, M., Heilbronner, R., Kunze, K., 1999. Orientation analysis of localized shear deformation in quartz fibres at the brittle-ductile transition. Tectonophysics 303, 83-107.

Van Noten, K., Claes, H., Soete, J., Foubert, A., Özkul, M., Swennen, R., 2013. Fracture networks and strike-slip deformation along reactivated normal faults in quaternary travertine deposits, Denizli Basin, western Turkey. Tectonophysics 588, 154-170.

Vernon, R.H., 2004. A Practical Guide to Rock Microstructure. Cambridge University Press.

Vernooij M.G.C. 2005. Dynamic Recrystallisation and Microfabric Development in Single Crystals of Quartz during Experimental Deformation (Unpublished PhD. thesis), Eidgenössische Technische Hochschule, Zürich.

Yin, A., Dubey, C.S., Kelty, T.K., Webb, A.A.G., Harrison, T.M., Chou, C.Y., Celerier, J., 2010. Geologic correlation of the Himalayan orogeny and Indian craton: Part 2: structural geology, geochronology, and tectonic evolution of the Eastern Himalaya. Geological Society of America Bulletin $122,360-395$. 